\title{
Performance Characteristics of Pollutants along the Longitudinal Profile of a Subsurface Flow Constructed Wetland Domestic Sewage Treatment Plant in the University of Lagos, Nigeria
}

\author{
Adelere Ezekiel Adeniran $^{1 *}$, Adetinuke Aina ${ }^{2}$, Omolaraeni Oshunrinade $^{2}$ \\ ${ }^{1}$ Department of Civil \& Environmental Engineering and Director of Works \& Physical Planning, University of Lagos, Lagos, Nigeria \\ ${ }^{2}$ Works and Physical Planning Department, University of Lagos, Lagos, Nigeria \\ Email: *engra@yahoo.com, ${ }^{*}$ eadeniran@unilag.edu.ng, adedokuntinuke@yahoo.com, laraspicey@yahoo.com
}

Received December 12, 2013; revised January 13, 2014; accepted February 9, 2014

Copyright (C) 2014 Adelere Ezekiel Adeniran et al. This is an open access article distributed under the Creative Commons Attribution License, which permits unrestricted use, distribution, and reproduction in any medium, provided the original work is properly cited. In accordance of the Creative Commons Attribution License all Copyrights (C) 2014 are reserved for SCIRP and the owner of the intellectual property Adelere Ezekiel Adeniran et al. All Copyright (C) 2014 are guarded by law and by SCIRP as a guardian.

\begin{abstract}
The paper reports the findings of a research work carried out to examine the performance and efficiency of a subsurface constructed wetland (SSFCW) for the treatment of domestic sewage in the University of Lagos (Unilag), Nigeria. The removal patterns and efficiencies of the physical, chemical and biological sewage pollutants parameters of domestic waste water generated within Unilag community by the SSFCW were studied. The wastewater was sampled and analysed along the SSFCW from influent (point1) to effluent (point 11). Total Dissolved Solids (TDS) reduced from $471 \mathrm{mg} / \mathrm{l}$ to $11.85 \mathrm{mg} / \mathrm{l}(97.48 \%)$, Turbidity reduced from $108.75 \mathrm{HTU}$ to 0.05HTU (99.95\%), Manganese reduced from $6.05 \mathrm{mg} / \mathrm{l}$ to $0.61 \mathrm{mg} /(89.92 \%)$, Nitrate reduced from $27.5 \mathrm{mg} / \mathrm{l}$ to $2.0 \mathrm{mg} / \mathrm{l}(92.73 \%)$, Sulphate reduced from $48.5 \mathrm{mg} / \mathrm{l}$ to $28 \mathrm{mg} / \mathrm{l}$ (42.27\%), Iron reduced from $1.13 \mathrm{mg} / \mathrm{l}$ to 0.03 $\mathrm{mg} / \mathrm{l}(97.35 \%)$, BOD reduced from $73.14 \mathrm{mg} / \mathrm{l}$ to $12.8 \mathrm{mg} / \mathrm{l}(82.5 \%)$, and $E$-coli reduced from $874 \mathrm{MPN} / 100 \mathrm{ml}$ to 0.15 MPN/100 ml (99.98\%). On the other hand, Dissolved Oxygen content increased along the SSFCW from 3.14 $\mathrm{mg} / \mathrm{l}$ to $7.49 \mathrm{mg} / \mathrm{l}(138.54 \%)$ while the $\mathrm{pH}$ improved from slightly acid level of 6.49 to slightly above neutral level of 7.05 (9.3\%). All the parameters at effluent point are within the Nigerian Federal Environmental Protection Agency (FEPA) acceptable standard. The study concludes that the SSFCW is a cheap, efficient and appropriate technology for the treatment of domestic sewage under tropical conditions.
\end{abstract}

\section{KEYWORDS}

Subsurface Flow; Constructed Wetland; Domestic Sewage; Pollutants Removal

\section{Introduction}

Raw sewage contains mostly water (about 95\%) which often comes from washing and flushing toilets. They also contain organic particles (such as faeces, food, paper fibres, plant materials, etc.), inorganic particles (such as sand, metal particles, ceramics, etc.), pathogens and nonpathogenic organism, animals such as protozoa, insects, etc., macro solids such as sanitary napkins, diapers etc., gases such as hydrogen sulphide, methane etc. and toxins amidst others. The rich and wide diversity of nutrients in

${ }^{*}$ Corresponding author. raw sewage makes them habitat for various organisms and plants.

All over the world, much wastewater is being generated and most of it, especially in developing countries, is not treated before being discharged into water bodies. Aquatic ecosystems are used either directly or indirectly as recipients of potentially toxic liquids from domestic, agricultural and industrial wastes [1]. Untreated or partially treated wastewater release is harmful to the environment, thus wastewater discharge should be regulated to protect the environment. About two-thirds of the population in developing countries have no hygienic means 
of disposing excreta and total wastewater which implies that inadequate sanitation is the prime cause of disease in such countries.

For more than two decades, countries have used constructed wetlands to improve the quality of contaminated water and wastewaters [2-4]. Constructed wetlands have successfully been used for environmental pollution control despite the fact that it was initially designed for use in domestic wastewater [5]. A constructed wetland system has the positive characteristics of a natural wetland and it duplicates the physical, chemical and biological processes in the natural system [6]. Constructed wetlands are artificial wastewater systems consisting of shallow ponds or channels which have been planted with aquatic plants and which act as biofilters through natural microbial, biological, physical and chemical processes to treat wastewater [7].

The plants in wetlands help to trap sediment because it allows the sediments to settle at lower velocities. The settlement of particles is also aided by laminar flows in most wetlands [8]. Also, gravity and differences in relative densities of suspended material allow particles to settle in the wetland [9]. Microorganisms in wetland soils take up and store nutrients and use them for metabolic functions which are crucial in organic pollutant removal. The bacteria use the carbon found in organic matter as an energy source and convert to carbon dioxide under aerobic conditions and to methane under anaerobic conditions. The microbial metabolism is the basis of removal of inorganic nitrogen [8].

The two major types of constructed wetlands are the Surface flow constructed wetland (SFCW) and the subsurface flow constructed wetland (SSFCW). The SFCW consists of a shallow basin, soil or other medium to support the roots of vegetation, and a hydraulically designed structure to maintain laminar flow of the sewage. The sewage water is opened to the atmosphere and mostly planted with floating wetland/aquatic plants. The SSFCW consists of a basin charged with a porous medium of graded gravel and sand. The water level is designed to remain below the top of the substrate. Constructed Wetlands can be a single cell basin. They can also be multiple cells connected in parallel or in series depending on configuration of available land space. Constructed wetlands are known to have a high buffering capacity. Effluent quality is therefore normally quite stable. Processes of pollutants removal include sedimentation, adsorption, complexation, uptake by plants, and microbially-mediated reactions including oxidation and reduction [10]. On the other hand, adverse effects can be expected from low temperatures (especially inhibition of $\mathrm{N}$-removal), peak flows (wash out of solids) and clogging of subsurface flow systems. Removal percentages are mainly dependent on temperature, hydraulic residence time (HRT) and loading rate [11].
In this paper, a subsurface flow constructed wetland, connected in series, used for the treatment of the domestic wastewater in the University of Lagos is studied to determine the pollutants' performance characteristics along its longitudinal profile.

\section{Materials and Methods}

\subsection{Study Area}

The University of Lagos, Lagos Nigeria (Unilag) is located in Lagos on $06^{\circ} 25^{\prime} \mathrm{N} 03^{\circ} 27^{\prime} \mathrm{E}$ on the West African Coast and has a direct link to the Lagos lagoon (Figure 1).

\subsection{Description of Unilag Subsurface Constructed Wetland}

The domestic sewage from the University community is conveyed in sewers to the central sewage inception chamber located at Services Area of the University. The sewage is pumped into two oxidation tanks. Large particles are screened off in a Screen/Grit Removal Chamber before moving into an anaerobic digester (Septic Tank) and then to the constructed wetland system (Figure 2). The wetland was achieved in reinforced concrete and lined with waterproof membrane to avoid infiltration and ground water pollution. The selection of the total area of the SSFCW was based on the model proposed by [12]. The total area of the SSFCW is $7200 \mathrm{~m}^{2}$ with an average sewage influent of $380 \mathrm{~m}^{3} /$ day. There are a total of nine (9) cells, each cell an area of $800 \mathrm{~m}^{2}$ and a depth of $0.65 \mathrm{~m}$. The nine cells are subsurface horizontal flow constructed wetland and contain different sizes of gravel and ocean sharp sand as the wetland media of average grade size $0.1 \mathrm{~mm}$ to $0.35 \mathrm{~mm}$ and planted with Cyprus papyrus. Figure 2 is the layout of the Constructed Wetland Sewage Treatment system

\subsection{Sample Collection and Analysis}

From January to December 2012 (52 weeks), three samples collected weekly at each of the Sample Points 1 to 11 (SP1-SP11) along the longitudinal profile of the constructed wetland system and taken to the laboratory for analysis. The mean values of each sampling point were recorded. The colour of the sample was measured using multi-parameter photometer after filtering using Whatman No. 42 filter paper. The conductivity, Turbidity, $\mathrm{pH}$ and total dissolved solids were measured using the Adwa conductivity meter, Hanna microprocessor turbidity meter, Beckman 350 pH meter and HM digital TDS meter respectively. Chemical and biological analyses were carried out for different parameters as stated for each parameter in Standard Methods of Water and Waste Water Analysis. Results of laboratory were further subjected to 


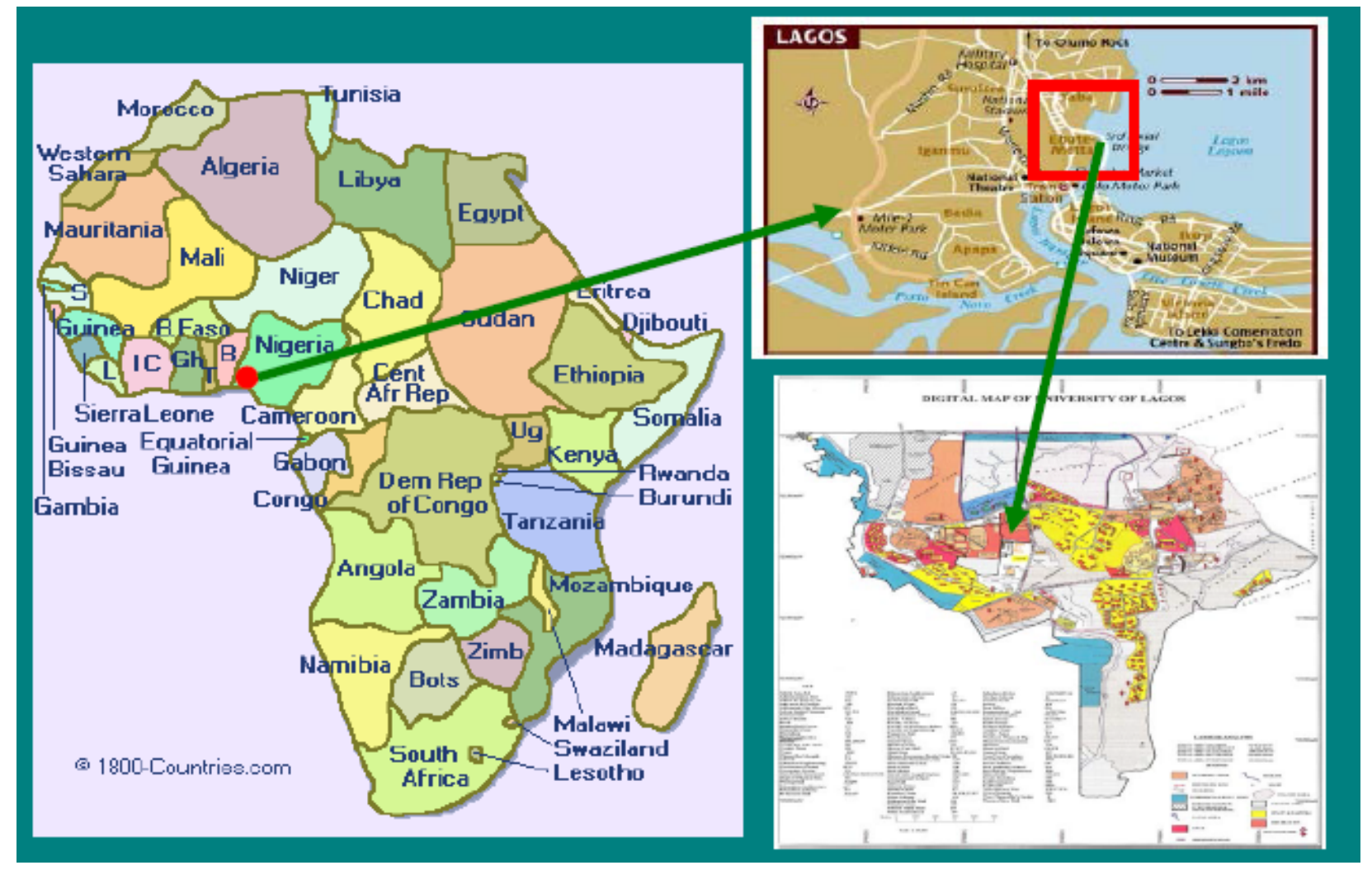

Figure 1. Map of the University of Lagos.

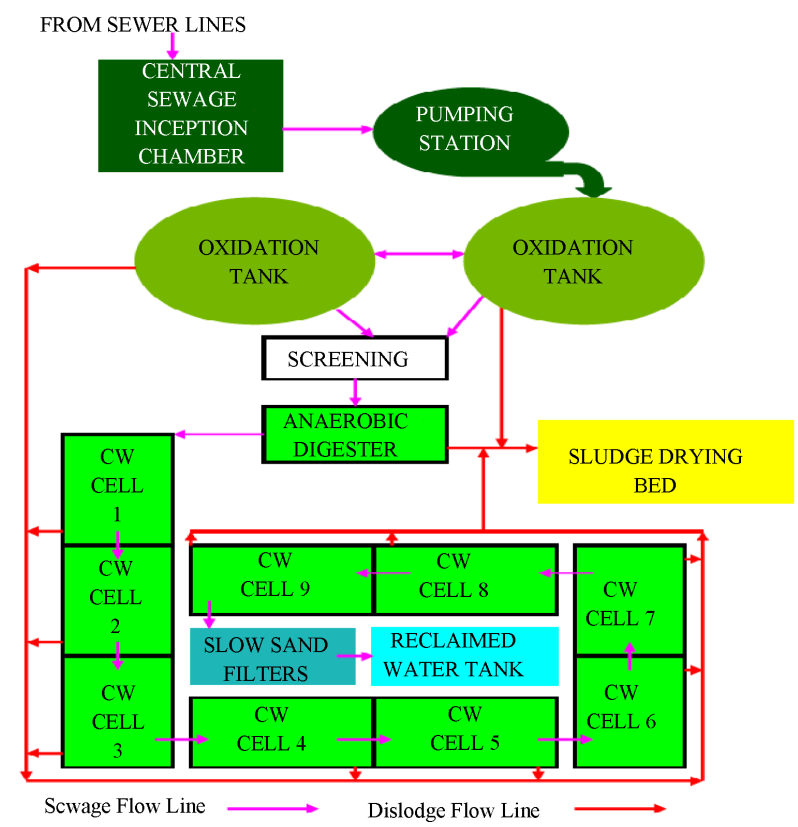

Figure 2. Layout of Unilag constructed wetland sewage system.

statistical analysis for means and standard deviations and presented in Table 1. Figure 3 shows the sketch of the longitudinal profile of the SSFCW and the sampling points.

\section{Results and Discussion}

\subsection{General Results}

The statistical analysis for means and standard deviations of the data collected for one year, are presented in Table 1 below for each of the pollutant parameters investigated.

Table 2 shows the percentage removal of the pollutants at the sampling points along the longitudinal profile of the SSFCW. It is observed that, although the SSFCW sewage treatment plant is designed and constructed in 9 cells connected in series, significant percentage of the pollutants have been removed at the end of cell 7, sampling point 8 (Table 2). The percentage reduction varies from $42.27 \%$ for Sulphate and $99.95 \%$ for Turbidity. For parameters that require desirable increase in levels, $\mathrm{pH}$ increased by $9.30 \%$, while the Dissolved Oxygen in-creased by 138.53\% (Table 2 and Figure 4). In Table 3 the performance of all the parameters, at the effluent point, of the SSFCW were compared with the FEPA guidelines for the Effluent Limitation for water to be discharged into receiving bodies of water in Nigeria. From the Table 3, it is observed that all the parameters are acceptable for discharge into the receiving water in accordance with FEPA Guidelines. The performance of each of the pollutant parameters are further discussed in the next section. 
Table 1. Mean values of parameters analysed in the domestic wastewater at sampling points along the SSFCW.

\begin{tabular}{|c|c|c|c|c|c|c|c|c|c|c|c|}
\hline \multirow{2}{*}{ Parameters } & \multicolumn{11}{|c|}{ Sampling Points (Mean Values and Standard Deviations of the Observations) } \\
\hline & 1 & 2 & 3 & 4 & 5 & 6 & 7 & 8 & 9 & 10 & 11 \\
\hline \multirow{2}{*}{$\mathrm{pH}$} & 6.49 & 7.34 & 7.43 & 7.76 & 7.54 & 7.67 & 7.49 & 7.52 & 7.11 & 7.06 & 7.05 \\
\hline & \pm 0.15 & \pm 0.13 & \pm 0.14 & \pm 0.12 & \pm 0.17 & \pm 0.19 & \pm 0.20 & \pm 0.15 & \pm 0.16 & \pm 0.04 & \pm 0.02 \\
\hline TDS & 471 & 463 & 459 & 429 & 397 & 267 & 230 & 145 & 120 & 45 & 11.85 \\
\hline$(\mathrm{mg} / \mathrm{l})$ & \pm 9.46 & \pm 9.25 & \pm 8.15 & \pm 7.25 & \pm 7.11 & \pm 5.05 & \pm 4.75 & \pm 2.15 & \pm 2.45 & \pm 0.95 & \pm 0.21 \\
\hline \multirow{2}{*}{ Turbidity HTU } & 108.75 & 82.32 & 62.58 & 45.61 & 11.53 & 3.45 & 2.67 & 1.61 & 1.19 & 2.39 & 0.05 \\
\hline & \pm 4.80 & \pm 3.74 & \pm 2.16 & \pm 2.05 & \pm 0.52 & \pm 0.17 & \pm 0.12 & \pm 0.06 & \pm 0.04 & \pm 0.10 & \pm 0.01 \\
\hline Mn & 6.05 & 4.44 & 3.31 & 2.85 & 1.4 & 0.79 & 0.73 & 0.72 & 0.7 & 0.66 & 0.61 \\
\hline$(\mathrm{mg} / \mathrm{l})$ & \pm 0.30 & \pm 0.22 & \pm 0.17 & \pm 0.12 & \pm 0.10 & \pm 0.03 & \pm 0.04 & \pm 0.03 & \pm 0.04 & \pm 0.03 & \pm 0.02 \\
\hline $\mathrm{NO}_{3}$ & 27.5 & 24.1 & 17.2 & 15.3 & 10.7 & 4.4 & 4.6 & 2.4 & 2.7 & 3.2 & 2.0 \\
\hline $\mathrm{SO}_{4}$ & 48.5 & 41.0 & 41.0 & 40.0 & 37.0 & 38.0 & 37.0 & 35.0 & 33.0 & 32.0 & 28.0 \\
\hline$(\mathrm{mg} / \mathrm{l})$ & \pm 0.97 & \pm 0.82 & \pm 0.84 & \pm 0.80 & \pm 0.74 & \pm 0.77 & \pm 0.74 & \pm 0.72 & \pm 0.68 & \pm 0.64 & \pm 0.58 \\
\hline $\mathrm{Fe}$ & 1.13 & 1.14 & 1.07 & 0.9 & 0.72 & 0.65 & 0.46 & 0.43 & 0.36 & 0.29 & 0.03 \\
\hline$(\mathrm{mg} / \mathrm{l})$ & \pm 0.11 & \pm 0.12 & \pm 0.09 & \pm 0.08 & \pm 0.07 & \pm 0.06 & \pm 0.04 & \pm 0.04 & \pm 0.03 & \pm 0.29 & \pm 0.01 \\
\hline DO & 3.14 & 2.38 & 3.05 & 2.85 & 5.15 & 5.76 & 5.84 & 6.59 & 6.84 & 6.79 & 7.49 \\
\hline$(\mathrm{mg} / \mathrm{l})$ & \pm 0.19 & \pm 0.14 & \pm 0.18 & \pm 0.17 & \pm 0.31 & \pm 0.35 & \pm 0.35 & \pm 0.40 & \pm 0.41 & \pm 0.41 & \pm 00.45 \\
\hline BOD & 73.14 & 54.58 & 53.05 & 42.85 & 35.15 & 35.76 & 25.84 & 26.59 & 26.84 & 18.79 & 12.8 \\
\hline$(\mathrm{mg} / \mathrm{l})$ & \pm 2.61 & \pm 1.92 & \pm 1.86 & \pm 1.50 & \pm 1.23 & \pm 1.27 & \pm 0.95 & \pm 0.93 & \pm 0.94 & \pm 0.66 & \pm 0.45 \\
\hline \multirow{2}{*}{ E. coli MPN/100 ml } & 874.18 & 854 & 753.95 & 712.85 & 650.15 & 545.67 & 358.84 & 175.59 & 89.39 & 79.86 & 0.15 \\
\hline & \pm 12.81 & \pm 11.51 & \pm 11.32 & \pm 10.70 & \pm 9.72 & \pm 8.19 & \pm 5.36 & \pm 2.63 & \pm 1.34 & \pm 1.19 & \pm 0.02 \\
\hline
\end{tabular}

Table 2. \% Removal of the pollutants at sampling points along the SSFCW profile.

\begin{tabular}{|c|c|c|c|c|c|c|c|c|c|c|c|}
\hline \multirow[t]{2}{*}{ Parameters } & \multicolumn{11}{|c|}{$\begin{array}{c}\text { Sampling Points } \\
\text { (\% Removal of Pollutants along the SSFCW Profile) }\end{array}$} \\
\hline & 1 & 2 & 3 & 4 & 5 & 6 & 7 & 8 & 9 & 10 & 11 \\
\hline $\mathrm{pH}$ & 0.00 & -13.80 & -15.19 & -20.31 & -16.90 & -18.91 & -16.12 & -16.59 & -10.23 & -9.46 & -9.30 \\
\hline TDS & 0.00 & 1.70 & 2.55 & 8.92 & 15.71 & 43.31 & 51.17 & 69.21 & 74.52 & 90.45 & 97.48 \\
\hline Turbidity & 0.00 & 24.30 & 42.46 & 58.06 & 89.40 & 96.83 & 97.54 & 98.52 & 98.91 & 97.80 & 99.95 \\
\hline $\mathrm{Mn}$ & 0.00 & 26.61 & 45.29 & 52.89 & 76.86 & 86.94 & 87.93 & 88.10 & 88.43 & 89.09 & 89.92 \\
\hline $\mathrm{NO}_{3}$ & 0.00 & 12.36 & 37.45 & 44.36 & 61.09 & 84.00 & 83.27 & 91.27 & 90.18 & 88.36 & 92.73 \\
\hline $\mathrm{SO}_{4}$ & 0.00 & 15.46 & 15.46 & 17.53 & 23.71 & 21.65 & 23.71 & 27.84 & 31.96 & 34.02 & 42.27 \\
\hline $\mathrm{Fe}$ & 0.00 & -0.88 & 5.31 & 20.35 & 36.28 & 42.48 & 59.29 & 61.95 & 68.14 & 74.34 & 97.35 \\
\hline DO & 0.00 & 24.20 & 2.87 & 9.24 & -64.01 & -83.44 & -85.99 & -109.87 & -117.83 & -116.24 & -138.54 \\
\hline BOD & 0.00 & 25.38 & 27.47 & 41.41 & 51.94 & 51.11 & 64.67 & 63.65 & 63.30 & 74.31 & 82.50 \\
\hline E. coli & 0.00 & 2.31 & 13.75 & 18.46 & 25.63 & 37.58 & 58.95 & 79.91 & 89.77 & 90.86 & 99.98 \\
\hline
\end{tabular}

\subsection{Performance of Physical Pollutants Parameters}

\subsection{1. $\mathrm{pH}$}

Figure 5(a) shows the $\mathrm{pH}$ pattern along the SSFCW in- dicating that there was no appreciable difference in in fluent $\mathrm{pH}$ value (6.49) and effluent $\mathrm{pH}$ value (7.05) and both are within FEPA standards (Table 3). The SSFCW system seems to reduce the acidity of the effluent water and thus it become more conducive for the aquatic life of 


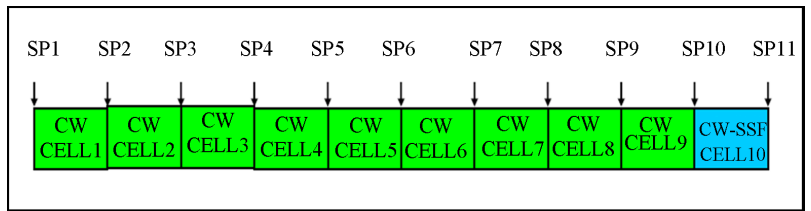

Figure 3. Sampling points along the longitudinal profile of the constructed wetland.

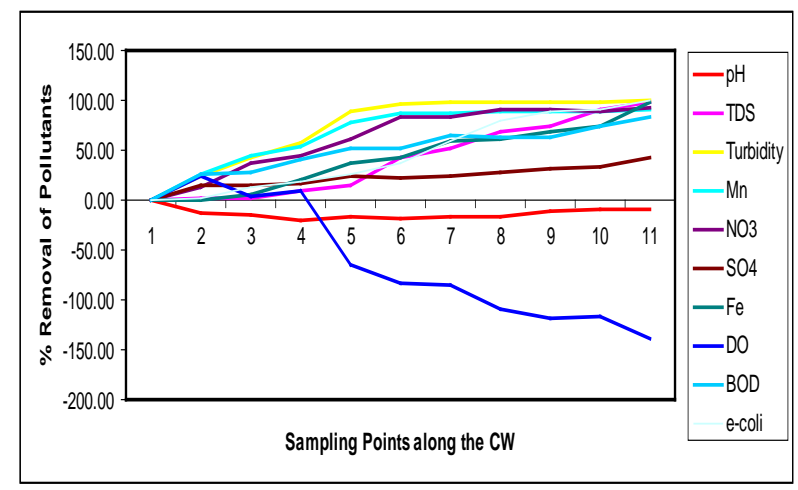

Figure 4. \% Reduction of pollutants at sampling points along the SSFCW.

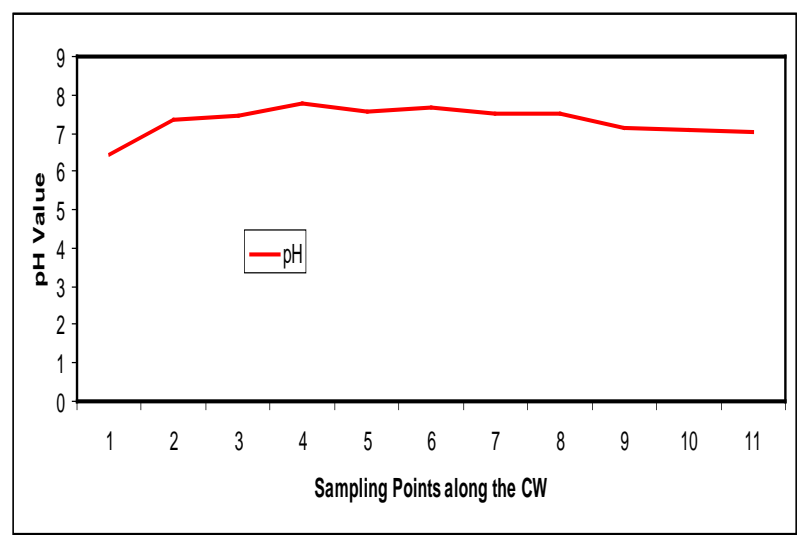

(a)

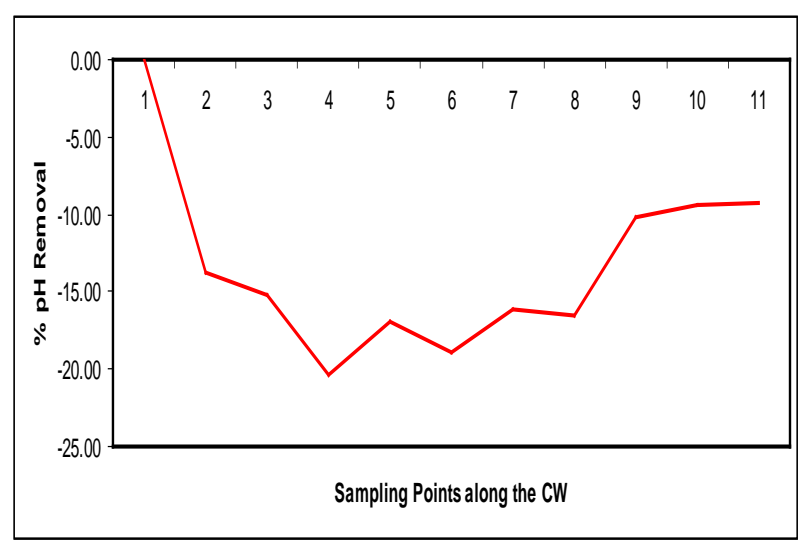

(b)

Figure 5. (a) $\mathbf{p H}$ values at sampling points of the SSFCW; (b) \% Removal of pH at sampling points of the SSFCW.
Table 3. Effluent Physical, chemical and Microbiological parameters compared with the Nigerian Effluent limitation Guidelines (FEPA, 1991).

\begin{tabular}{ccccc}
\hline Parameter & Units & $\begin{array}{c}\text { Unilag } \\
\text { SSFCW } \\
\text { Sewage } \\
\text { Plant } \\
\text { Effluent }\end{array}$ & $\begin{array}{c}\text { Limit for } \\
\text { discharge to } \\
\text { surface water }\end{array}$ & Remarks \\
\hline $\mathrm{PH}$ & & 7.43 & $6-9$ & Acceptable \\
TDS & $\mathrm{mg} / \mathrm{l}$ & 11.85 & 2000 & Acceptable \\
$\begin{array}{c}\text { Turbidity } \\
\text { Dissolved } \\
\text { oxygen }\end{array}$ & $\mathrm{HTU}$ & 0,05 & Not stated & Acceptable \\
$\begin{array}{c}\text { Iron(Fe) } \\
\text { Sulphate }\end{array}$ & $\mathrm{Mg} / \mathrm{l}$ & 7.49 & Not Stated & Acceptable \\
$\begin{array}{c}\text { Nitrate } \\
\text { Manganese } \\
\text { (Mn) }\end{array}$ & $\mathrm{Mg} / \mathrm{l}$ & 28.0 & 10 & Acceptable \\
$\begin{array}{c}\text { E. coli } \\
\text { BOD } / 1\end{array}$ & $\mathrm{MPN} / 100$ & 0.03 & 500 & Acceptable \\
Bl & $\mathrm{Mg} / \mathrm{l}$ & 12.80 & 10 & Acceptable \\
\hline
\end{tabular}

the receiving water body. Figure 5(b) shows the percentage reductions of $\mathrm{pH}$ along the longitudinal profile of the SSFCW are increasingly negative.

This observation implies that the treatment process of the SSFCW improves the acidity of the sewage from slightly acidic level to an acceptable slightly above neutral level.

\subsubsection{Total Dissolved Oxygen (TDS)}

From Table 1 the TDS value of the influent was 471 $\mathrm{mg} / \mathrm{l}$ while that of effluent was $11.85 \mathrm{mg} / \mathrm{l}$. The reduction of the pollutants varied increasingly from SP1 to SP11.

A final percentage of about $97.48 \%$ was achieved at the effluent point (Table 2). It is also observed from Table 2 that more $50 \%$ of the TDS has been removed between SP1 and SP7. The result is consistent with results obtained by $[13,16]$. Figures 6 (a) and (b) show the TDS removal performance and the percentage removal at the sampling points along the longitudinal profile of the SSFCW respectively.

\subsubsection{Turbidity}

From Table 1, the turbidity value of the influent (SP1) was $108.75 \mathrm{HTU}$ while the effluent (SP2) had a turbidity value of 1.98HTU. Table 2 shows that the constructed wetland removed about $99.95 \%$ of the turbidity. It is also observed from Table 2 that more $50 \%$ of the Turbidity has been removed at sampling point 4 . The significant decrease in turbidity can be attributed to the fact that there is a decrease in Total dissolved and suspended solids. Efficiency of constructed wetland in the removal of turbidity may depend on the sand granules, soil particle 
sizes and depth of the bed [14]. Figures 7(a) and (b) show the Turbidity removal performance and the \% removal at the sampling points along the longitudinal profile of the SSFCW respectively.

\subsection{Performance of Chemical Pollutant Parameters}

\subsubsection{Manganese}

A gradual decrease was observed in Manganese content of the wastewater along the SSFCW from influent level of $6.05 \mathrm{mg} / \mathrm{l}$ to effluent $0.61 \mathrm{mg} / \mathrm{l}$ (Table 1). Figure 8(a) shows the removal level of Manganese at the sampling points of the SFCW while Figure 8(b) shows the percentage removal at the sampling points along the longitudinal profile of the SFCW. It was observed that more than 50\% removal of Manganese has been achieved at sample point 4 , while the percentage removal at effluent point (SP11) was $89.92 \%$.

\subsubsection{Nitrate}

Appreciable Nitrate removal was also achieved along the SSFCW from influent $27.5 \mathrm{mg} / \mathrm{l}$ to effluent $2.0 \mathrm{mg} / \mathrm{l}$ (Table 1). Nitrate pollutant removal efficiency of $92.73 \%$ was achieved at SP11 and more than 50\% of removal efficiency was achieved at SP 5 (Table 2). Figure 9(a)

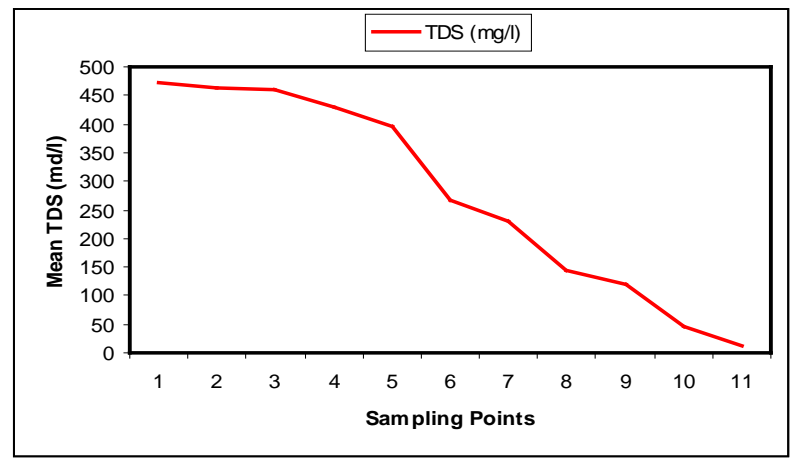

(a)

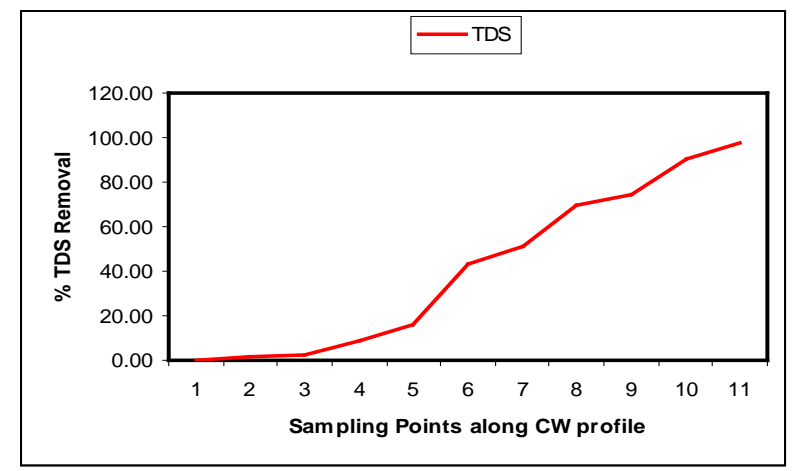

(b)

Figure 6. (a) TDS values at sampling points of the SSFCW; (b) \% Removal of TDS at sampling points of the SSFCW.

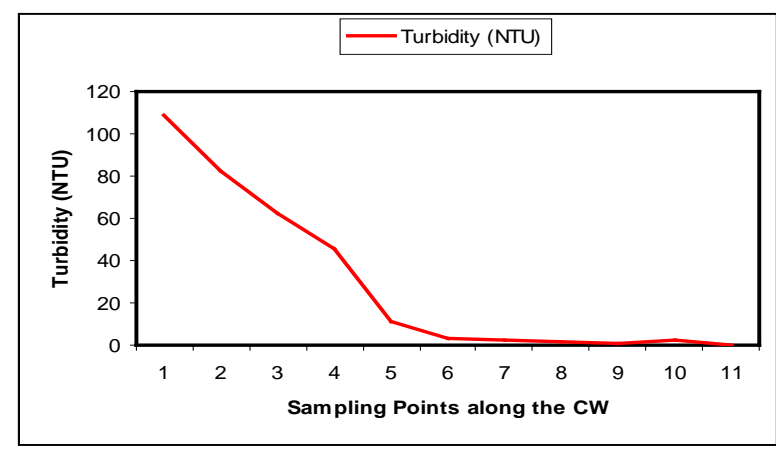

(a)

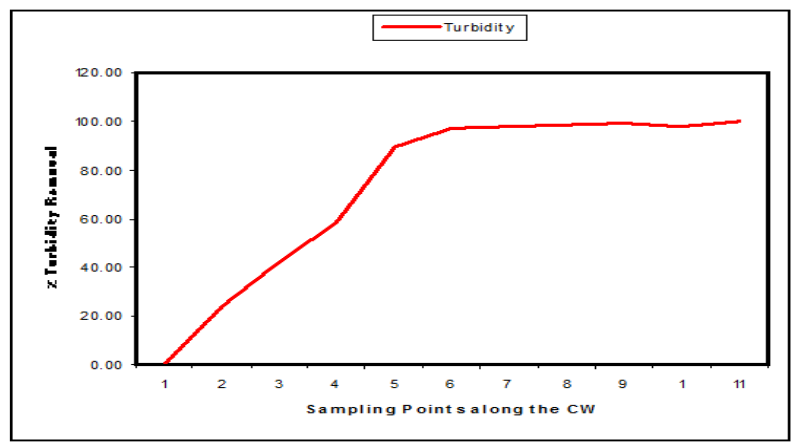

(b)

Figure 7. (a) Turbidity values at sampling points of the SFCW; (b) \% turbidity removal at sampling points of the SFCW.

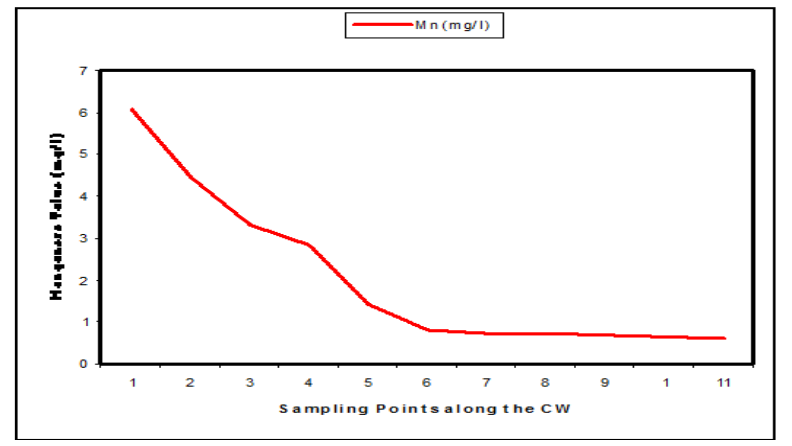

(a)

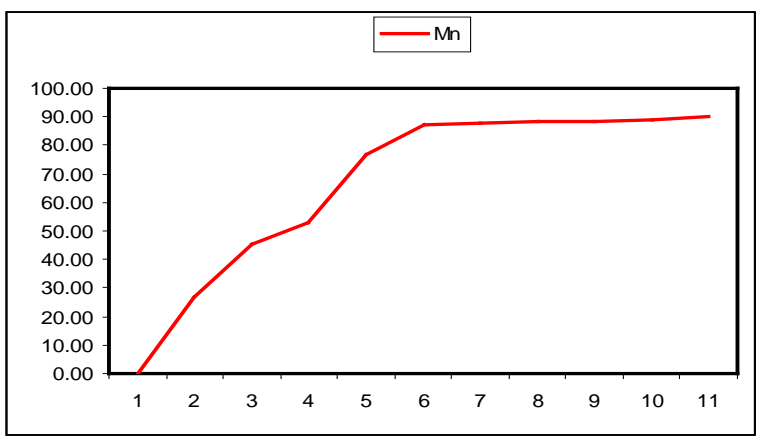

(b)

Figure 8. (a) Mn values at sampling points of the SSFCW; (b) \% Mn removal at sampling points of the SSFCW. 
shows the removal level of Nitrate at the sampling points of the SSFCW while Figure 9(b) shows the percentage removal of Nitrate at the sampling points along the longitudinal profile of the SSFCW. Nitrate removal in wetlands is usually very high [8]. The importance of Nitrate removal in sewage before discharging the effluent to the receiving water cannot be over emphasised. High concentration of Nitrates in drinking water can cause "blue baby" syndrome in infants [15]. High amounts of nitrogen also contribute to eutrophication in which nutrients promote excessive plant growth where plants deplete oxygen in the water [6].

\subsubsection{Sulphate}

Sulphate is classified as non toxic constituent of water. However, intake of water containing high sulphate content can cause diarrhoea. The presence of sulphate in domestic wastewater may be due to the addition of detergent wastes from washing [16]. Figure 10(a) shows that the SSFCW in this study was not very efficient in removing sulphates from the wastewater. The influent wastewater had $48.5 \mathrm{mg} / \mathrm{l}$ sulphate while the effluent had $28 \mathrm{mg} / \mathrm{l}$ sulphate (Figure 10(a)), and this is a removal of only about $42.27 \%$ (Figure 10(b)). Despite the rather low removal percentage, the effluent sulphate concentration is still far less than the FEPA discharge specification of $400 \mathrm{mg} / \mathrm{l}$.

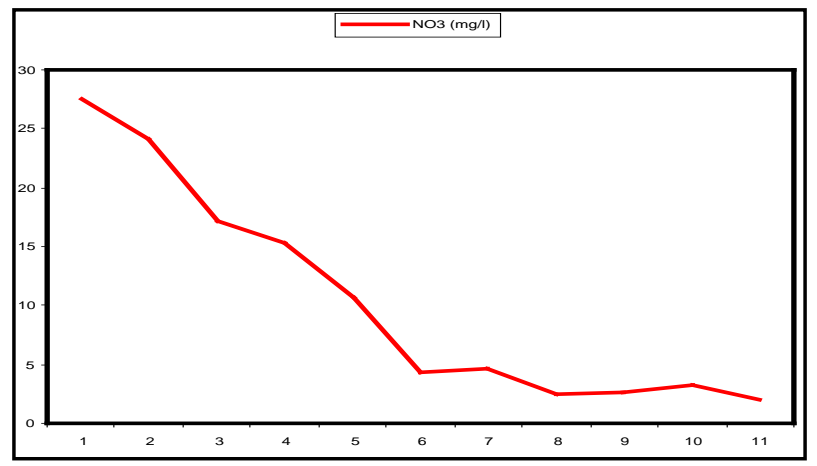

(a)

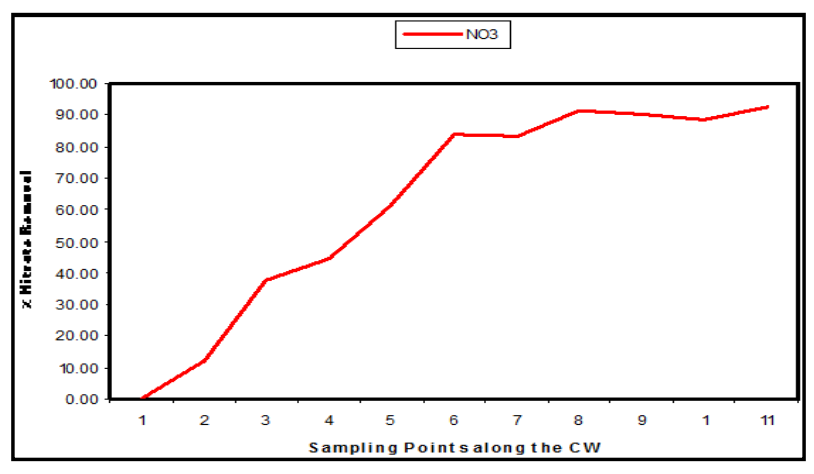

(b)

Figure 9. (a) $\mathrm{NO}_{3}$ values at sampling points of the SSFCW; (b) \% $\mathrm{NO}_{3}$ removal at sampling points of the SSFCW.

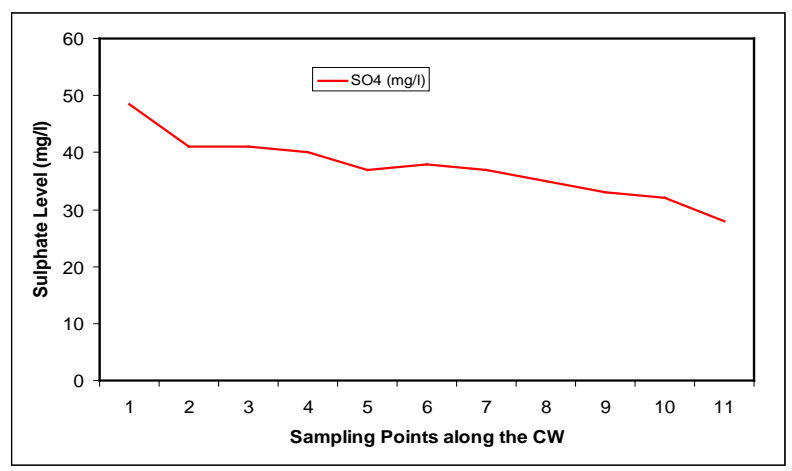

(a)

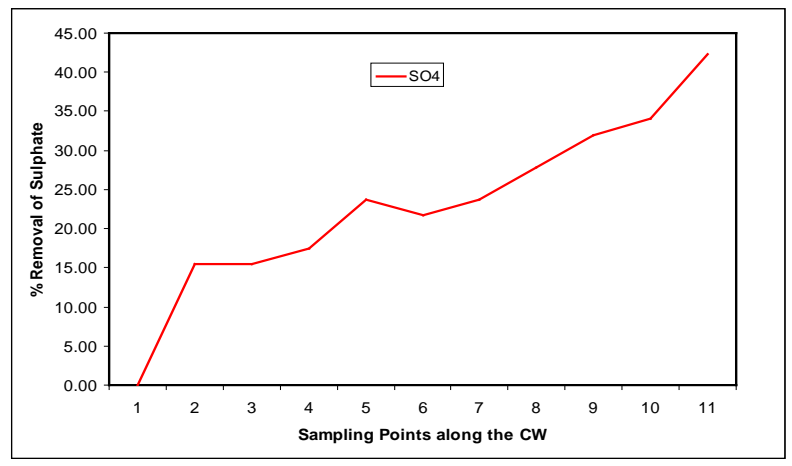

(b)

Figure 10. (a) $\mathrm{NO}_{3}$ values at sampling points of the SSFCW; (b) $\% \mathrm{NO}_{3}$ removal at sampling points of the SSFCW.

\subsubsection{Iron}

Figure 10(a) shows the steady reduction in the iron content of the wastewater along the SSFCW from influent from $1.13 \mathrm{mg} / \mathrm{l}$ to effluent $0.03 \mathrm{mg} / \mathrm{l}$ (Table 1 and Figure 11(a)) and an overall removal efficiency of $97.35 \%$ (Table 2 and Figure 11(b)). The effluent concentration is thus within the limit of FEPA standards.

\subsubsection{Dissolved Oxygen}

A healthy body of water should have a dissolved oxygen of at least $5.2 \mathrm{mg} / \mathrm{l}$ [17]. Low oxygen concentration is associated with heavy organic matter contamination [14]. In this study, DO value increased along the SSFCW from influent (SP1) with a value of $3.14 \mathrm{mg} / \mathrm{l}$ to the effluent point (SP11) with a value of $7.49 \mathrm{mg} / \mathrm{l}$ (Figure 12(a)), an improvement efficiency of about 138.54\% (Figure 12(b)). The negative decline seen in the percentage curve (Figure 12(b)) signifies the fact that the DO was increasing along the sampling point.

The improvement noticed in dissolved oxygen after treatment in the constructed wetland may be due to re-duction in organic pollutants and microbial population due to their retention in the beds and simultaneous mixing of atmospheric oxygen [14]. Also, there is oxygen exchange between the roots of the plants, the microbio logical activities of the organism and the water flowing 


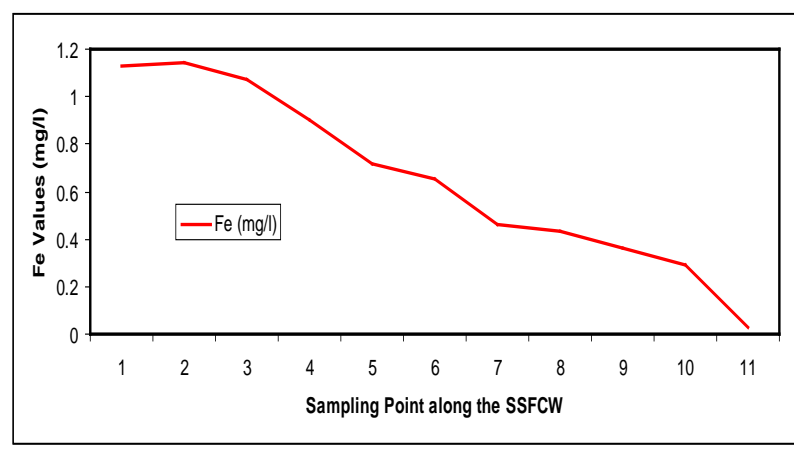

(a)

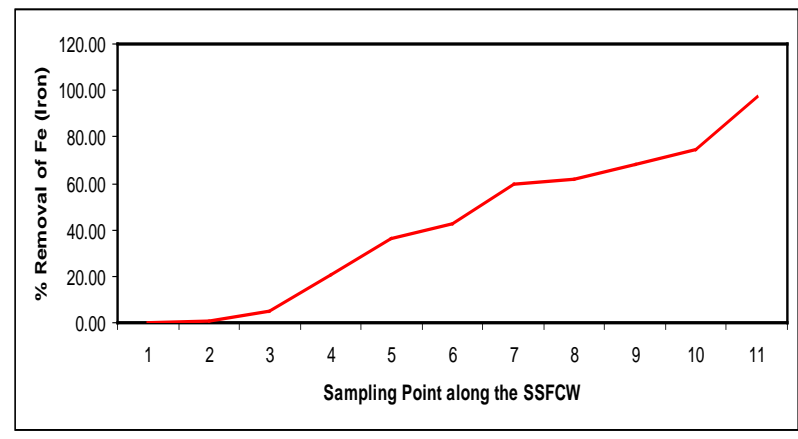

(b)

Figure 11. (a) Fe values at sampling points of the SSFCW; (b) \% Fe removal at sampling points of the SSFCW.

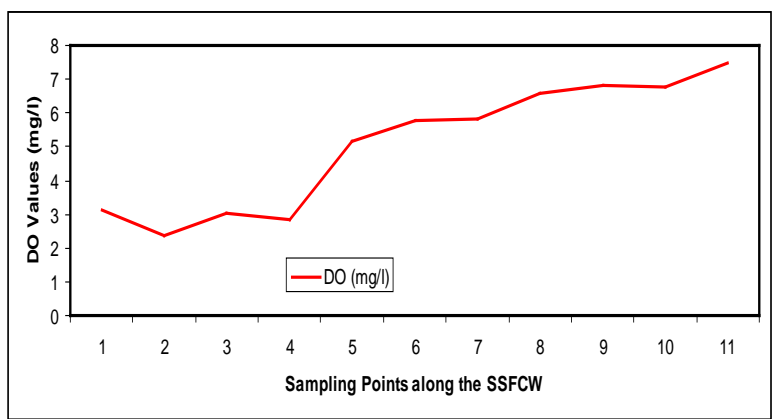

(a)

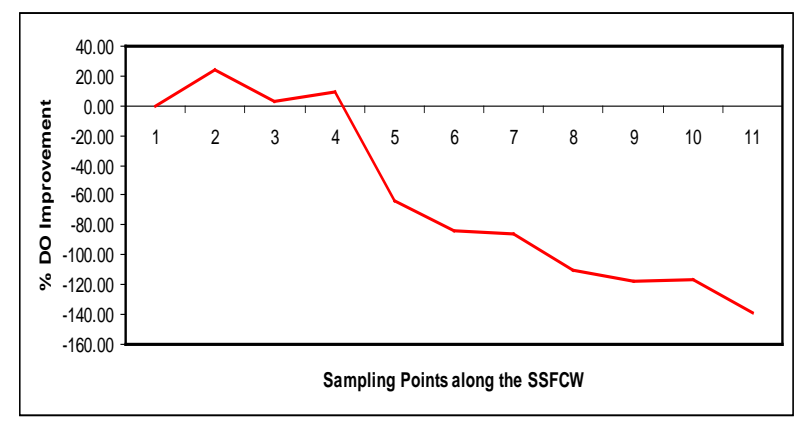

(b)

Figure 12. (a) Fe values at sampling points of the SSFCW; (b) \% Fe removal at sampling points of the SSFCW.

in the constructed wetland [18].

\subsubsection{Biochemical Oxygen Demand (BOD)}

Biochemical oxygen demand is used to measure how much oxygen microorganisms are consuming to break down organics.

There should be enough oxygen in the water of the wetland to ensure survival of plants and animals [8]. In the current study, BOD values in the SSFCW decreased from $73.14 \mathrm{mg} / \mathrm{l}$ at influent point (SP1) to a value of (12.80 mg/l) at effluent point (SP11) i.e. about 82.47\% removal efficiency (Figures 13(a) and (b)).

Constructed wetlands are known to be highly efficient in reduction of BOD $[6,13,14,19]$. The physical removal of BOD5 occurs rapidly through settling and entrapment of particulate matter in the void spaces in the gravel or rock media. Soluble BOD5 is removed by the microbial growth on the media surfaces and attached to the plant roots and rhizomes penetrating the bed. In constructed wetland system, a fraction of BOD5 is produced within the system due to the composition of plant litter and other naturally occurring organic materials, thus making it impossible to achieve complete BOD5 removal and a residual BOD5 is typical present in the effluent [20].

\subsection{Performance of Microbiology Pollutants Parameters}

\section{Escherichia coli (E-coli)}

A measure of the microbiology quality of sewage is

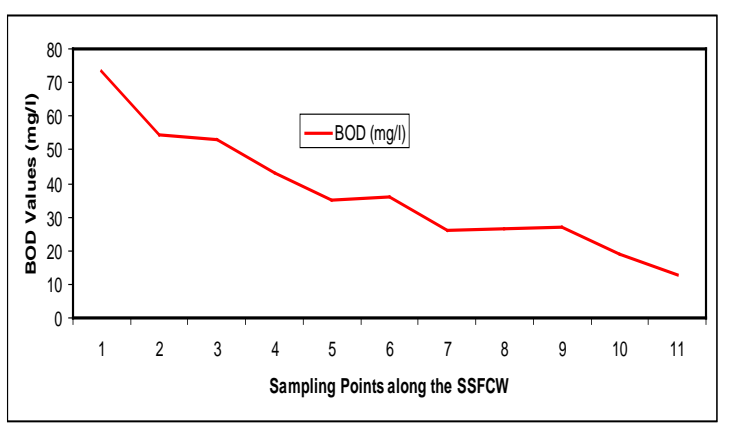

(a)

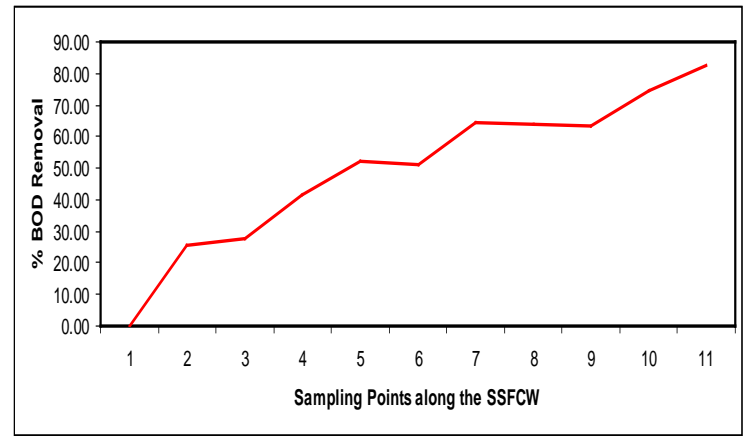

(b)

Figure 13. (a) BOD values at sampling points of the SSFCW; (b) \% BOD removal at sampling points of the SSFCW. 
usually through the E-coli. E-coli is a disease causing pathogen that can be present in drinking water and most definitely in sewage water.

This study reveals an appreciable reduction in total E-coli count from $874.18 \mathrm{MPN} / 100 \mathrm{ml}$ at influent point (SP1) to a value of $0.15 \mathrm{MPN} / 100 \mathrm{ml}$ at effluent point (SP11), this is a removal efficiency of about $82.50 \%$ (Figures 14(a) and (b)).

The main processes that are involved with pathogen removal include natural die-off, sedimentation, filtration, ultra-violet light ionization, unfavorable water chemistry, temperature effects, $\mathrm{pH}$ and predation by other organisms [21]. Also, the depth of the beds plays a significant role in the reduction of bacterial populations [14]. The depth of the constructed wetland in this study is $650 \mathrm{~mm}$, which is shallow, may also account for the better efficiency in coliform removal.

\section{Conclusion}

Results from this study show that the constructed wetland system at the University of Lagos is efficient in the removal of biological and organic pollutants from domestic waste water. The removal efficiency of the facility for most physical, chemical and biological parameters is above average and the effluent values are within the

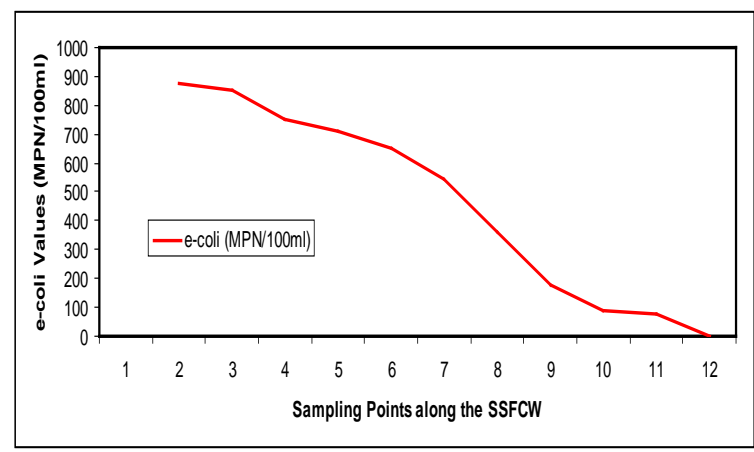

(a)

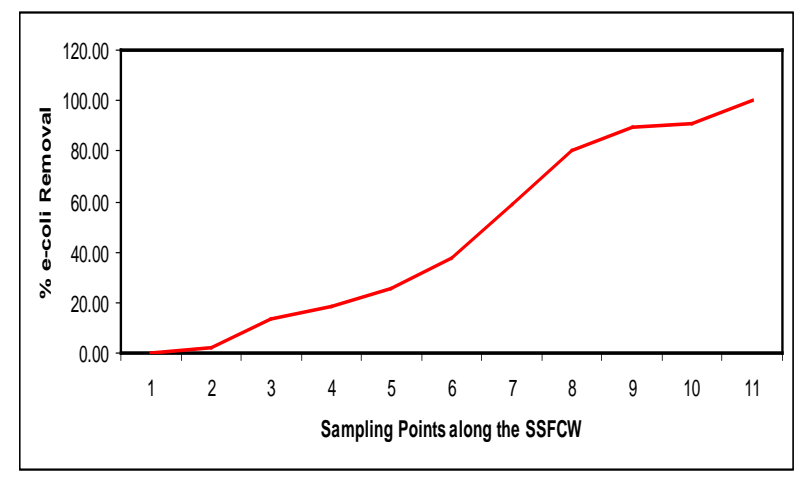

(b)

Figure 14. (a) E-coli values at Sampling Points of the SSFCW; (b) \% E-coli Removal at Sampling Points of the SSFCW.
FEPA's Effluent Limitation Guidelines in Nigeria [22] as shown. The study concludes that constructed wetland, apart from being a cheap and viable option for sewage treatment in Tropical Africa, is also efficient in the removal of pollutants during the treatment process.

\section{REFERENCES}

[1] D. Demirezen, A. Aksoy and K. Uruc, "Effect of Population Density on Growth, Heavy Metals by the Aquatic Plants Potamogeton pectinatus L. and Potarnogeton Biomass and Nickel Accumulation Capacity of Lemna gibba (Lemnaceae)," Chemosphere, Vol. 66, No. 3, 2007, pp. 553-557. http://dx.doi.org/10.1016/j.chemosphere.2006.05.045

[2] C. B. Zhang, J. Wang, W. L. Liu, S. X. Zhu, D. Liu, S. X. Chang, J. Chang and Y. Ge, "Effects of Plant Diversity on Nutrient Retention and Enzyme Activities in a Fullscale Constructed Wetland,” Bioresource Technology, Vol. 101, No. 6, 2010, pp. 1686-1692.

http://dx.doi.org/10.1016/j.biortech.2009.10.001

[3] M. A. Maine, N. Suné, H. Hadad, G. Sanchez and C. Bonetto, "Influence of the Malaianus Miq and Their Potential Use for Contamination Indicators and in Wastewater Treatment," Science of the Total Environment, Vol. 392, 2009, pp. 22-29.

[4] C. L. Murray-Gulde, G. M. Huddleston, K. V. Garber and J. H. Rodgers, "Contributions of Schoenoplectus californicus in a Constructed Wetland System Receiving Copper Contaminated Wastewater," Water Air Soil Pollution, Vol. 163, No. 1-4, 2005, pp. 355-378. http://dx.doi.org/10.1007/s11270-005-1297-3

[5] M. Scholz and B.-H. Lee, "Constructed Wetlands: A Review," International Journal of Environmental Studies, Vol. 62, No. 4, 2005, pp. 421-447.

[6] A. E. Adeniran, "The Efficiency of Water Hyacinth (Eichornia crassipes) in the Treatment of Domestic Sewage in an African University," AWRA 2011 Annual Water Resources Conference, Albuquerque, 7-10 November 2011.

[7] USEPA, "Manual. Constructed Wetlands Treatment of Municipal Wastewaters,” EPA/625/R-99/010, United States Environment Protection Agency, Office of Research and Development, Cincinnati, 2000.

[8] W. F. DeBusk, "Wastewater Treatment Wetlands: Applications and Treatment Efficiency," Soil and Water Science Department, University of Florida, SL156, 1999.

[9] Interstate Technology \& Regulatory Council, “Technical \& Regulatory Guidance for Constructed Treatment Wetlands,” United States Environmental Protection Agency, 2003.

[10] J. S. Weis and P. Weis, "Metal Uptake, Transport and Release by Wetland Plants: Implications for Phytoremediation and Restoration,” Environment International, Vol. 30, No. 5, 2004, pp. 685-700.

http://dx.doi.org/10.1016/j.envint.2003.11.002

[11] D. P. L. Rousseau, E. Lesage, A. Story, P. A. Vanrolleghem and N. De Pauw, "Constructed Wetlands for Water 
Reclamation,” Desalination, Vol. 218, No. 1-3, 2008, pp. 181-189.

http://dx.doi.org/10.1016/j.desal.2006.09.034

[12] J. Vymazal and L. Kropfelova, "Wastewater Treatment in Constructed Wetlands with Horizontal Sub-Surface Flow," Springer, Netherlands, 2008.

[13] I. O. Asia and E. E. Akporhonor, "Characterization and Physicochemical Treatment of Wastewater from Rubber Processing Factory," International Journal of Physical Sciences, Vol. 2, No. 3, 2007, pp. 61-67.

[14] G. Prasad, R. Rajeev and A. K. Chopra, "Sand Intermittent Technology for Safer Domestic Sewage Treatment," Journal of Applied Sciences and Environmental Management, Vol. 10, No. 1, 2006, pp. 73-77.

[15] P. L. Kempster, H. R.Van Vliet and A. Kuhn, “The Need for Guidelines to Bridge the Gap between Drinking Water Quality and That Which Is Practically Available and Acceptable Water," Water SA, Vol. 23, No. 2, 1997, pp. 163-167.

[16] S. Dipak and D. Arti, "Assessment and Treatment of Municipal Wastewater of Indore City of India," Archives of Applied Science Research, Vol. 3, No. 1, 2011, pp. 450461.http://scholarsresearchlibrary.com/archive.html
[17] C. M. A. Ademoroti, "Environmental Chemistry and Toxicology,” Foludex Press Ltd., Ibadan, 1996, pp. 134- 146.

[18] P. S. Burgoo, "Performance of Subsurface Flow Wetlands with Batch-Load and Continuous-Flow Conditions,” Water Environment Research, Washington DC, 1995.

[19] A. O. Babatunde, Y. Q. Zhao, M. O’Neill and B. O’Sullivan, "Constructed Wetlands for Environmental Pollution Control: A Review of Developments, Research and Practice in Ireland,” Environment International, Vol. 34, No. 1, 2008, pp. 116-126. http://dx.doi.org/10.1016/j.envint.2007.06.013

[20] W. T. Stringfellow, J. S. Hanlon, S. E. Borglin and N. W. T. Quinn, "Comparison of Wetland and Agriculture Drainage as Sources of Biochemical Oxygen Demand to the Sao Joaquin River, California,” Agricultural Water Management, Vol. 95, No. 5, 2008, pp. 527-538. http://dx.doi.org/10.1016/j.agwat.2007.12.007

[21] R. H. Kadlec and R. L. Knight, "Treatment Wetlands," 1st Edition, CRC Press, Boca Raton, 1996.

[22] FEPA, "Effluent Limitation Guidelines for Discharge of Pollutants in Bodies of Water in Nigeria,” Federal Environmental Protection Agency, Nigeria, 1991. 